Acta regionalia et environmentalica 2

Nitra, Slovaca Universitas Agriculturae Nitriae, 2013, p. 63-70

\title{
SLOVAKIA ON THE ROAD TOWARDS THE EU KNOWLEDGE BASED ECONOMY
}

\author{
Libor KABÁT
}

\author{
Slovak University of Agriculture in Nitra, Slovakia
}

\begin{abstract}
The European Union has passed a complicated period. Its economy lags not only behind its own development goals, but in many developing indicators, it lags well behind the results achieved by its economic partners and competitors, the USA and Japan. Due to the lower competitiveness in the international market environment there are growing problems in the domestic labour market. For a long time, many EU countries demonstrated relatively high unemployment leading subsequently to weakening the income situation of households and consequently to social tensions in society. The labor market situations of young graduates and also people approaching retirement age and seniors are particularly worrying. In the context of such arguments the strategy of perspective development of the European Union 2020 known as the EUROPE 2020 strategy was born. Its essence is the formulation of objectives and procedures to enable to "build in the area of the EU the strongest and most effective economic grouping of the world, able to absorb and eliminate negative stimuli from the external market environment in order to protect the quality of life of its inhabitants." According to J. Barroso, Europe 2020 is "the strategy for growth for the future decades, which must ensure building the European Union as an area of knowledge based, constantly growing and inclusively functioning economy". The paper confronts the EU strategic objectives of 2020 with the current economic and social conditions under the EU and Slovakia's environment as a precondition for their successful fulfillment. The situation in the current Slovak labour market is used as a pointer to the neglected national labour policy tools, which could create significant barriers in realization of the EU 2020 goals. The initially presented data will be used for building the econometric model enabling the in-depth analysis of relation between the explanatory variables and the newly generated economic and social parameters in the EU and Slovakia.
\end{abstract}

Keywords: economic growth, social development, innovation, education

The ongoing economic crisis in the European Union requires a long-term strategic vision to be formulated for the development of this socio-political and economic colossus in addition to urgent interventions to improve the economic environment. Special emphasis should be put on a more consistent alignment of the objectives of economic growth with the social development of the society and conditions of long term sustainability of the development.

In the long term, the attention has been drawn to the need for such fundamental changes not only in the technical literature but also by extensively developed civil activities. One of the most important documents, which opened broad discussion in this field and which also explicitly and in a highly qualified manner answers the issues related to a new understanding of the economic growth objectives, is the report of the Stiglitz-Sen Commission (Stiglitz, 2010). This report initiated a broad theoretical discussions on the measurement of economic growth results, and it drew a particularly urgent attention to and emphasized a need for targeted focusing on the economic growth in order to react in a maximum extent to the expectations of the society in ensuring the quality of life of its members, while exploiting natural resources in a sustainable manner. The report emphasized the need for a new ways of measurement of economic growth and social development of the society as a multi-functional process which results in improving the quality of life of members of the society.

The EU 2020 strategy requires an active participation of the educational institutions in its development and support. The paper presents the current situation in the labour market, where evident disproportions between market demand for labor force and supply of school graduates exist, where even highly educated and trained labour force has limited chances to find the adequate employment positions. The identification of the core explanatory factors influencing this situation is formulated as the research topic.

\section{Theoretical Background}

In the context of these reflections, a strategy of perspective European Union development by 2020 was born, also known as EUROPE 2020 (EUROPA, 2012). At the heart of this strategy there is the formulation of the objectives and procedures to enable "the most powerful and efficient economic coalition to be built in the EU environment, able to absorb and eliminate negative external market stimuli in order to protect the quality of life of its inhabitants." According to Barroso "...Europe 2020 is the growth strategy for the decades to come which should ensure the European Union is built as an area of knowledge, constantly developing and inclusively operating economy". In this context, the role of the new development strategy should be emphasized in ensuring a higher employment level, raising labour productivity and ensuring the necessary social cohesion in the whole EU area and individual Member States.

In EUROPE 2020, the urgency of innovative changes in the economy of European countries is presented as a special role. The document draws attention to the EU lagging behind the partners like USA, Japan and BRIC countries in technology. Innovative tasks require not only a significant increase in financial resources, but also purposeful and carefully considered change in education at all school levels, and accelerated transfer of science and research results into practice. 


\section{Material and methods}

In this paper, we analyze the Europe 2020 strategic framework and objectives in the context of current issues and challenges addressed by Slovakia. We focus especially on the area of innovative activities and related educational tasks. Based on statistical data, we disclose the "weaknesses" of Europe 2020, and failure to meet conditions for successful implementation of this project by the Member States.

\section{Current situation on the labour market in the area of the European Union}

Employment. The European Union is faced with pertaining economic and social problems. Its economy lags behind not only their own development goals, but in many developing indicators it lags well behind the results achieves by the USA (Joint, 2006; Reshaping, 2012) and Japan (EU-Japan,
2012; Joint, 2012), its economic partners and competitors. Due to a lower competitiveness in the international market environment, there are growing social problems on domestic market. Labour market characteristics are of particular concern. For a long period, the lower level of workforce $(62 \%)$ is employed than in the economy of the U.S.A. (66.6\%) and Japan $(70.1 \%)$ which reduces its production potential. For more detailed information, broken down into age groups of 15-24 and 55-64, see Table 1.

However, the significant differences in the employment of working population are also among the countries of the Union (Zoppe, 2011). The biggest differences are evident in the age group of 15-24, with the workforce employment in the new EU Member States being 20-30\%; the lowest level is reported in Hungary (18.1\%). On the other hand, the employment rate is significantly higher in the economically successful EU countries - the Netherlands 63.3\%, Denmark $55.0 \%$ and Austria 54.6\%.

Table 1 Employment in the EU according to the age groups

\begin{tabular}{|c|c|c|c|c|c|}
\hline \multirow[t]{2}{*}{ Country } & \multirow[t]{2}{*}{ Total employment } & \multicolumn{2}{|c|}{$15-24$ years $(3)$} & \multicolumn{2}{|c|}{ 55-64 years } \\
\hline & & (\%) of total & in 1000 & (\%) of total & in 1000 \\
\hline EU27 & 216052 & 32.9 & 71081 & 48.9 & 105650 \\
\hline Bulgaria & 2934 & 21.9 & 643 & 45.7 & 1341 \\
\hline Cyprus & 389 & 28.1 & 109 & 50.7 & 197 \\
\hline Czech Rep. & 4890 & 25.2 & 1232 & 49.3 & 2411 \\
\hline Estonia & 624 & 33.0 & 206 & 60.6 & 378 \\
\hline Hungary & 3878 & 18.6 & 721 & 36.9 & 1431 \\
\hline Latvia & 886 & 28.7 & 254 & 52.8 & 468 \\
\hline Lithuania & 1279 & 21.6 & 276 & 51.8 & 662 \\
\hline Malta & 173 & 43.8 & 76 & 33.6 & 58 \\
\hline Poland & 15591 & 24.7 & 3851 & 38.7 & 6034 \\
\hline Romania & 9263 & 23.9 & 2214 & 41.4 & 3835 \\
\hline Slovakia & 2329 & 20.1 & 468 & 43.1 & 1004 \\
\hline Slovenia & 924 & 27.3 & 252 & 32.9 & 304 \\
\hline Austria & 4184 & 54.6 & 2284 & 43.1 & 1803 \\
\hline Belgium & 4524 & 25.3 & 1145 & 39.5 & 1787 \\
\hline Denmark & 2689 & 55.0 & 1479 & 60.8 & 1635 \\
\hline Finland & 2483 & 41.8 & 1038 & 58.2 & 1445 \\
\hline France & 25798 & 28.8 & 7430 & 44.5 & 11480 \\
\hline Germany & 40062 & 46.6 & 18669 & 61.5 & 24638 \\
\hline Greece & 3763 & 13.1 & 493 & 36.4 & 1370 \\
\hline Ireland & 1838 & 28.2 & 518 & 49.3 & 906 \\
\hline Italy & 22899 & 18.6 & 4259 & 40.4 & 9251 \\
\hline Luxembourg & 236 & 21.7 & 51 & 41.0 & 97 \\
\hline Netherlands & 8424 & 63.3 & 5333 & 58.6 & 4937 \\
\hline Portugal & 4635 & 23.6 & 1094 & 46.5 & 2155 \\
\hline Spain & 17282 & 18.2 & 3145 & 43.9 & 7587 \\
\hline Sweden & 4657 & 40.2 & 1872 & 73.0 & 3400 \\
\hline
\end{tabular}

Source: Eurostat, author's calculation 
The situation is similar in the age group 55-64, where the lowest employment rate within the group of new Member States is reported by Slovenia, Malta, Hungary and Poland (from 32\% to 38\%). The "old" Member States reported much higher employment rate in this age group as well (Heyes, 2013). In Sweden, it is up to $73 \%, 61.5 \%$ in Germany and $58 \%$ to $60 \%$ in Denmark, Finland, the Netherlands, and the UK.

Unemployment. Besides the low employment rate, the Union is confronted with serious labour market problems, i.e. with high unemployment. Currently, there are more than 26 million people unemployed in the EU countries (Eurostat, March, 2013), which is almost $11 \%$ of the available labour force. The unemployment rate in Member States varies considerably (Paci, 2011). The highest unemployment rate is in Greece (27\%), Spain (26\%), Portugal (17\%) and Slovakia (14\%). The lowest unemployment rate is reported to be in Austria (4.7\%), Germany (5.4\%) and Luxembourg (5.7\%); see Figure 1

Comparing the unemployment rate in the EU countries for the period from 2007 to the present time, the unemployment rate grew the most in Ireland, Spain, Greece and Cyprus. In the same period of time, the unemployment rate dropped in Germany, Poland and Austria.

The development of unemployment rate has been alarming in the group of young people up to 25 years old (Figure 2). The group includes the graduates of all levels of school including universities. The highest unemployment rate among the young people aged under 25 is currently reported in Greece (60\%), Spain (56\%), in Italy, Portugal and Slovakia it is more than $34 \%$.

Long-term unemployment (Sperman, 2005) with the unemployed for more than 1 year seems to be a persistent problem. The period of time they have spent without employment makes their current chances to respond to the labour market needs difficult or even impossible.

In the new Member States, the most complicated situation in the long term is in Slovakia; in 2012, it accounted for more than $67 \%$ of

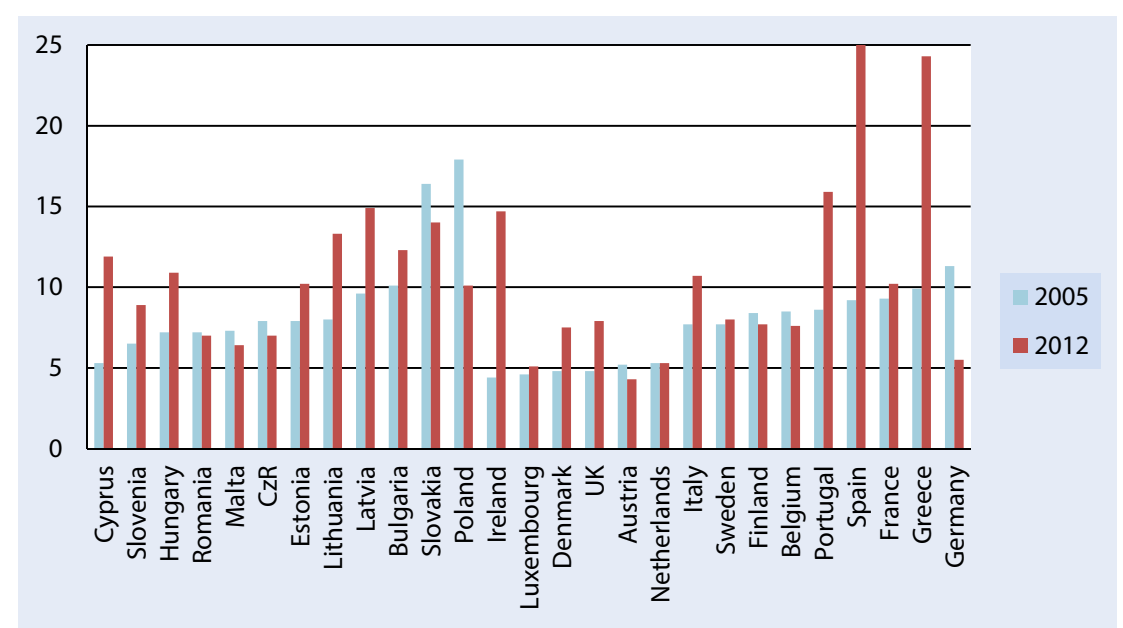

Figure 1 Total unemployment in 2005 and $2012 \%$ of total labour force Source: Eurostat, March, 2013, author

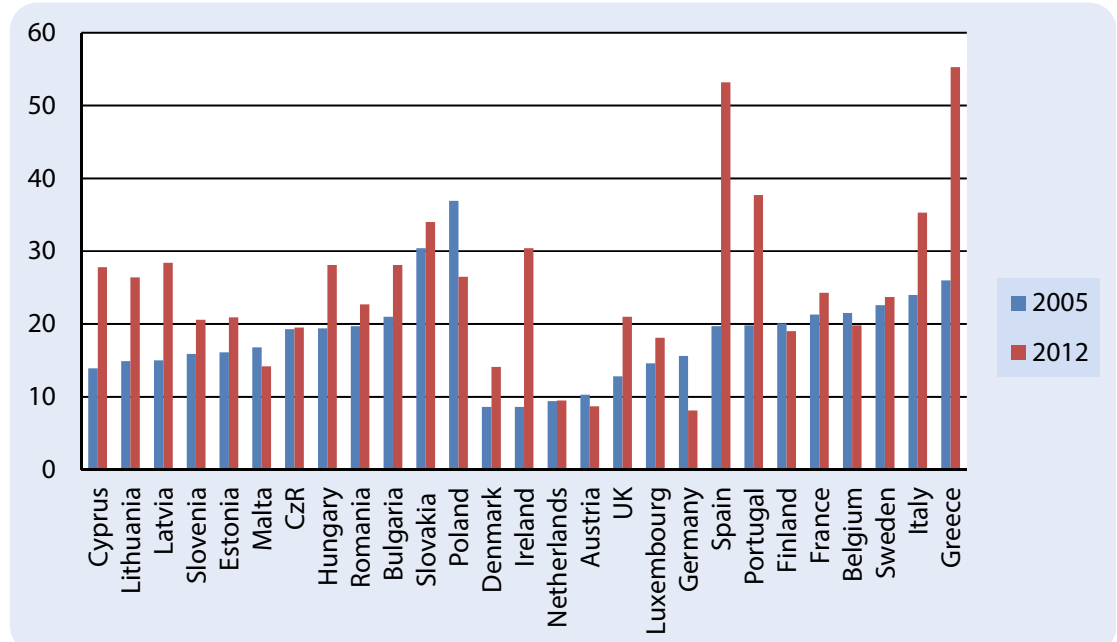

Figure 2 Unemployment of young people below 25 years in \% of this age labour force

Source: Eurostat, March, 2013, author

the total unemployment rate. In the old Member States, the long-term unemployment rate is the highest in Ireland (61\%).

A more detailed analysis shows that the situation in the labour market is characterized by significant structural differentiation in supply and demand for skilled labour force. For an extended period of time, the labour market is entered by the graduates of social and humanities fields, which fails to correspond with the needs of innovative and competitive labour market. The situation in Slovakia, where only $34.1 \%$ of graduates in 2012 specialized in technical studies, while $65.9 \%$ of graduates finished humanities, serves as example (ÚIPMŠ, 2012). Even in this context, the questions may be asked whether employers' organizations formulate their requirements for the professional profile of graduates clearly enough and in advance and whether educational institutions monitor and respond adequately to these needs of the labour market.

Unemployment of school graduates, Table 2, is a particular problem that needs to be very carefully analyzed and effectively addressed in connection with the preparation for the implementation of the EUROPE 2020 strategy (Roth, 2010). In connection with the objectives of the EUROPE 2020 strategy, special attention should be drawn to a significant increase of the share of unemployed graduates of tertiary education in 2007-2012 in the new Member States, except for Malta. In this regard, it would be necessary to 
Table 2 Unemployment by age and level of education

\begin{tabular}{|c|c|c|c|c|c|c|c|c|c|c|c|c|}
\hline \multicolumn{13}{|c|}{ Age 25-64 years } \\
\hline \multirow[t]{2}{*}{ Country } & \multicolumn{3}{|r|}{ Total } & \multicolumn{3}{|c|}{ ISCED 0-2 } & \multicolumn{3}{|c|}{ ISCED 3-4 } & \multicolumn{3}{|c|}{ ISCED 5-6 } \\
\hline & 2007 & 2012 & change to 2007 & 2007 & 2012 & change to 2007 & 2007 & 2012 & change to 2007 & 2007 & 2012 & change to 2007 \\
\hline EU27 & 7.2 & 10.6 & 3.4 & 10.9 & 18.6 & 7.7 & 7.0 & 9.6 & 2.6 & 4.0 & 6.1 & 2.1 \\
\hline Bulgaria & 6.9 & 12.4 & 5.5 & 18.0 & 28.5 & 10.5 & 5.8 & 11.7 & 5.9 & 2.4 & 5.9 & 3.5 \\
\hline Cyprus & 4.0 & 12.1 & 8.1 & 5.1 & 14.2 & 9.1 & 4.0 & 12.9 & 8.9 & 3.4 & 10.4 & 7.0 \\
\hline Czech Rep & 5.4 & 7.0 & 1.6 & 20.4 & 28.8 & 8.4 & 4.7 & 6.5 & 1.8 & 1.7 & 2.9 & 1.2 \\
\hline Estonia & 4.8 & 10.4 & 5.6 & 11.7 & 24.7 & 13.0 & 4.9 & 10.7 & 5.8 & 2.5 & 6.2 & 3.7 \\
\hline Hungary & 7.4 & 11.0 & 3.6 & 17.5 & 24.9 & 7.4 & 6.6 & 10.7 & 4.1 & 2.9 & 4.5 & 1.6 \\
\hline Latvia & 6.1 & 15.2 & 9.1 & 10.8 & 27.1 & 16.3 & 5.9 & 17.7 & 11.8 & 3.7 & 6.5 & 2.8 \\
\hline Lithuania & 4.4 & 13.5 & 9.1 & 7.7 & 34.8 & 27.1 & 5.1 & 16.7 & 11.6 & 2.1 & 5.6 & 3.5 \\
\hline Malta & 6.5 & 6.5 & 0.0 & 8.6 & 9.4 & 0.8 & 4.0 & 4.8 & 0.8 & 2.2 & 2.2 & 0.0 \\
\hline Poland & 9.7 & 10.2 & 0.5 & 16.5 & 20.3 & 3.8 & 10.3 & 11.0 & 0.7 & 4.7 & 5.7 & 1.0 \\
\hline Romania & 6.8 & 7.3 & 0.5 & 8.6 & 8.1 & -0.5 & 6.9 & 7.6 & 0.7 & 3.0 & 5.6 & 3 \\
\hline Slovakia & 11.2 & 14.0 & 2.8 & 45.1 & 44.7 & -0.4 & 9.4 & 13.5 & 4.1 & 4.1 & 6.9 & 2.8 \\
\hline Slovenia & 5.0 & 9.0 & 4.0 & 7.4 & 15.7 & 8.3 & 5.0 & 9.2 & 4.2 & 3.3 & 6.1 & 2.8 \\
\hline Austria & 4.5 & 4.4 & -0.1 & 8.8 & 9.1 & 0.3 & 3.7 & 3.9 & 0.2 & 2.5 & 2.1 & -0.4 \\
\hline Belgium & 7.5 & 7.6 & 0.1 & 13.0 & 14.2 & 1.2 & 7.6 & 7.8 & 0.2 & 3.8 & 4.0 & 0.2 \\
\hline Denmark & 3.8 & 7.7 & 3.9 & 5.7 & 12.1 & 6.4 & 3.0 & 6.9 & 3.9 & 3.0 & 4.9 & 1.9 \\
\hline Finland & 6.9 & 7.8 & 0.9 & 13.0 & 16.6 & 3.6 & 7.1 & 8.3 & 1.2 & 3.6 & 3.9 & 0.3 \\
\hline France & 8.0 & 9.9 & 1.9 & 12.3 & 16.3 & 4.0 & 7.2 & 9.9 & 2.7 & 5.5 & 5.7 & 0.2 \\
\hline Germany & 8.8 & 5.6 & -3.2 & 17.3 & 12.6 & -4.7 & 8.3 & 5.4 & -2.9 & 3.9 & 2.4 & -1.5 \\
\hline Greece & 8.4 & 24.5 & 16.1 & 7.8 & 26.4 & 18.6 & 9.8 & 27.5 & 17.7 & 7.1 & 18.2 & 11.1 \\
\hline Ireland & 4.6 & 15.0 & 10.4 & 7.6 & 25.9 & 18.3 & 4.4 & 17.7 & 13.3 & 2.7 & 7.6 & 4.9 \\
\hline Italy & 6.2 & 10.8 & 4.6 & 7.5 & 13.9 & 6.4 & 5.7 & 10.1 & 4.4 & 4.5 & 6.8 & 2.3 \\
\hline Luxembourg & 4.1 & 5.2 & 1.1 & 5.8 & 8.5 & 2.7 & 3.4 & 5.2 & 1.8 & 3.2 & 3.6 & 0.4 \\
\hline Netherlands & 3.2 & 5.3 & 2.1 & 5.3 & 8.4 & 3.1 & 2.9 & 5.0 & 2.1 & 1.8 & 3.2 & 1.4 \\
\hline Portugal & 8.5 & 16.4 & 7.9 & 8.7 & 17.5 & 8.8 & 8.2 & 17.7 & 9.5 & 7.6 & 12.0 & 4.4 \\
\hline Spain & 8.3 & 25.2 & 16.9 & 10.5 & 34.0 & 23.5 & 8.1 & 24.5 & 16.4 & 5.3 & 15.1 & 9.8 \\
\hline Sweden & 6.2 & 8.1 & 1.9 & 12.2 & 18.2 & 6.0 & 5.4 & 7.2 & 1.8 & 3.6 & 4.4 & 0.8 \\
\hline UK & 5.4 & 8.0 & 2.6 & 9.5 & 14.4 & 4.9 & 5.2 & 8.7 & 3.5 & 2.6 & 4.3 & 1.7 \\
\hline
\end{tabular}

Source: Eurostat, March, 2013, prepared by the author

analyze the factors leading to such development in more details. Surely, these questions should be answered by the national agencies, monitoring their labour markets and employment rates by qualification structure and national economy industries. It would be useful to examine the relevance or the compliance of university fields of study and programs with qualification requirements presented in the labour market. Universities should also be responsible for monitoring of these relationships and requirements and adjust their own educational programs accordingly. Analogous findings and requirements can also be formulated in relation to secondary-level schools (ISCED 3-4). In this case, however, the decision on the changes in the curriculum is made by central educational authorities.
Between 2007 and 2011, the unemployment rate grew further in the EU. Despite repeated appeals and demands to raise the level of education of the workforce, the negative development also affects job applicants with the second and tertiary education level completed, see Figure 3 . High increase in the number of unemployed is reported especially by the Baltic countries affected by deep economic recession (Kattel, 2009). For graduates of the highest level of education, the situation deteriorated most in Cyprus and in the Baltic countries as well. Even the results of Slovakia may not be considered a good step towards the implementation of the EUROPE 2020 strategy.

The high level of unemployment rate in the new EU Member States but also in several "old" EU Member States is the most serious problem. Its extend requires systematic 


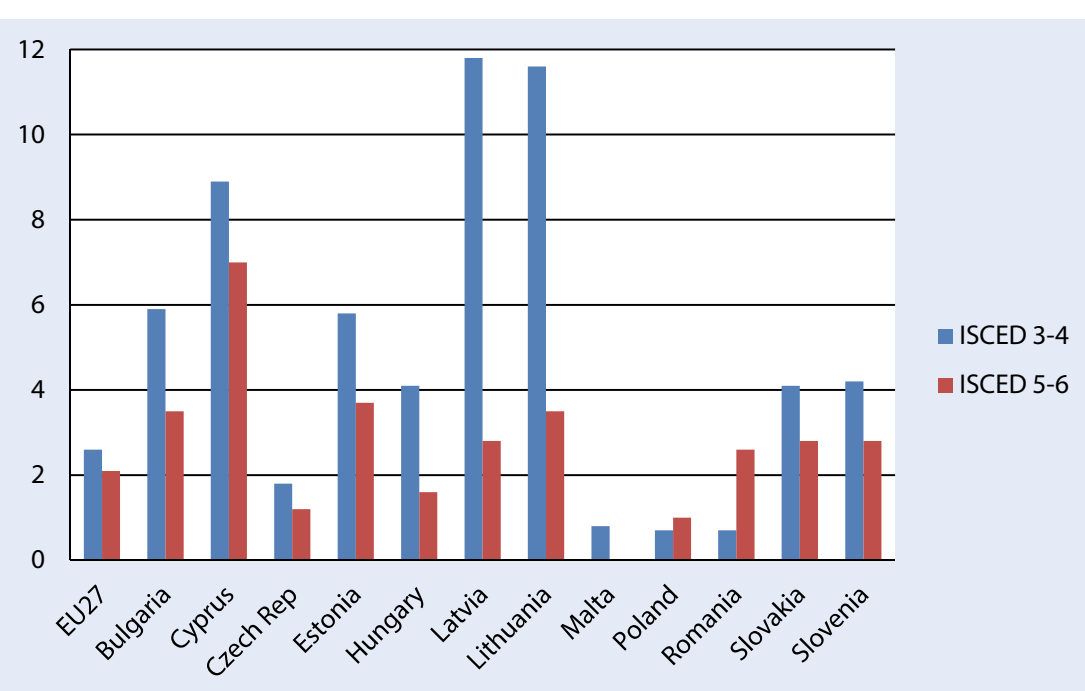

Figure 3 Increase in unemployment of the ISCED 3-4 and 5-6 levels graduates since 2007 in \%

Source: OECD, October, 2012, author

effort and economic policies of individual countries coherent with resources released by the Union for inclusive economic growth. This solution is not only required, but forced by the strategic agenda of Europe 2020. Equally, the higher responsibility of the governmental bodies setting the quotas of graduates in relevant educational branches should act more proactively in a close cooperation with the employers' associations.

\section{Social impacts - the problem of poverty in the EU environment}

The unfavorable labour market situation is not only an economic problem of the Union and its Member States. Persistent or rather deepening unfavorable social situation of the population and particularly high number of population at risk of poverty are logical consequences of this situation In the EU, the current

share of population at risk is $24 \%$, or nearly 120 million people of all ages and social groups. For more detailed data for Slovakia and neighbouring countries (Visegrad Countries and Slovenia) see Table 3.

Detailed analysis shows that certain social and age groups of population are at risk of poverty with even higher level of probability than average figures suggest. In most countries, the most vulnerable groups include young people, children, families, single parents and seniors groups of inhabitants.

Risk of poverty, together with the possible social exclusion becomes evident in more difficult social realization of individuals and whole families. For families with children, it is also their access to educational institutions and programs which is at risk and may subsequently endanger their healthy psychological development. Risk of poverty also

Table 3 Population at risk of poverty and social exclusion in Visegrad countries and Slovenia

\begin{tabular}{|l||c|c|c|}
\hline Country & In millions & In \% & $\begin{array}{c}\text { Number of people at risk of poverty } \\
\text { under 25 years in 1000 }\end{array}$ \\
\hline \hline EU27 & 24.2 & 19.6 & 13000 \\
\hline Czech Republic & 1.6 & 15.3 & 169 \\
\hline Hungary & 3.1 & 31 & 345 \\
\hline Poland & 10.2 & 27.2 & 1025 \\
\hline Slovakia & 1.1 & 20.6 & 115 \\
\hline Slovenia & 0.4 & 19.3 & 32 \\
\hline
\end{tabular}

brings significant social tensions (Nolan, 2010) and the loss of social security of the population, which undermines the initiative of individuals and work teams.

However, only a healthy society may aspire to the successful implementation of new and ambitious development goals as envisaged in the strategic agenda of Europe 2020. It is therefore in the spotlight of the European Union and all Member States to eliminate the escalation of the social tensions in Europe and eliminate or at least reduce its resources as quickly as possible.

The EUROPE 2020 strategy suggests basic development directions that the Union and its Member States should follow in their search for the path to higher intensity of innovative programs, increased competitiveness and higher labour productivity.

\section{Europe 2020 - strategic objectives}

The EUROPE 2020 document (Marlier, 2010) defines eight major problem areas with their development objectives for 2020 for the whole Union, as well as for the individual Member States. The following areas are subject to special monitoring and checked for objectives:

1. Employment issue.

2. Intensification of research, development and innovation and strengthening of competitiveness.

3. Control and reduction of greenhouse gas emissions.

4. Renewable energy resources.

5. Energy Consumption.

6. Early termination of educational and vocational programs.

7. ertiary Education.

8. Population at risk of poverty.

All criteria reflect current issues of economic and social development, and pay attention to the major environmental problems, as reported by the Stiglitz-Sen report.

The three (marked bold) of the mentioned criteria have a direct impact on the system of education of respective Member States. Intensification of research and subsequent strengthening of the innovation potential requires the active participation of educational institutions of these countries. Nevertheless, critical comments 
repeatedly addressed to these countries (for the alleged failure to fulfill these tasks) require expert analysis and finding real ways out of this situation. Based on the available data, it can be shown that educational institutions are not the only "weak" link in the development of innovation potential in the EU countries.

Continuous assessment of the economic and social development in the area of the European Union in relation to the above mentioned strategic areas is constructed based on the new criteria with an emphasis on monitoring and evaluation of modernization and innovative elements in the manufacturing sector, i.e. the elements that should provide required increase in the competitiveness of the European Union and its Member States in international economic area.

Evaluation results for each country of the Union are presented by the European innovation mechanism which is part of EUROPE 2020 as a new tool of evaluation based on the same methodology. This tool monitors especially the innovative outputs of EU27 countries and using SWOT analysis, it monitors their other attributes as well and identifies weaknesses in providing innovative potential of the Union and its Member States.

\section{Non-fulfilled tasks and expected economic effects}

Despite the repeatedly presented intentions of the European Union to increase the co-participation of the Member States in increasing production and economic competitiveness of its Member States on the world markets, the development objectives defined by the Europe 2020 strategy fail to be fulfilled consistently. Most of the countries build their scientific and research potential and innovative capacities in a minimum extent. The resources allocated to scientific research and tertiary educations (PhD programs) are well below the expected 3\% of GDP, except for a few countries (Denmark, Finland, Germany, Sweden). In Slovakia, it is only $0.63 \%$, and $0.77 \%$ in Poland. The highest contribution to research and development among the new member states is allocated by the Czech Republic (1.84\%).

Based on the assessment of the EU countries according to the above mentione criteria using the methodology of the European Innovation mechanism (Fagerberg,
2005, Hollanders, 2008), it may be indicated that by the participation of Member States in the innovation processes of the Union, the Member States are classified as follows: Innovation leaders:

- Denmark, Finland, Germany and Sweden. Their innovation activity and outputs are well above the EU average.

Innovation followers:

- Austria, Belgium, Cyprus, Estonia, France, Ireland, Luxembourg, the Netherlands, Slovenia and the UK. These countries have scores around the EU average.

Moderate innovators:

- the Czech Republic, Greece, Hungary, Italy, Malta, Poland, Slovakia and Spain. Their results are below the EU average.

Modest innovators:

- Bulgaria, Latvia, Lithuania and Romania significantly lag behind the EU countries average in their results.

For Slovakia's current position with regard to the mentioned criteria and its strategic objectives and tasks for 2020 see Table 4.

Slovakia, as well as all Member States of the Union adopted a challenging target tasks the performance of which would significantly affect not only its economic potential, but above all its ability to consistently meet tasks and objectives defined on a pan-European level and social development objectives. Special attention should be paid to the commitment of the countries to increase the contribution to support the innovation process up to $1 \%$ GDP in new Member States and up to $3 \%$ in old Member Countries by 2020.

Based on the present negative development of employment, it is necessary to ensure the reduction of unemployment and especially unemployment of the young people at the age of 25 through innovative changes of the production. To solve this problem it is necessary to consider and implement mainly active forms of impacts on the labour market, creating new jobs, supporting small and mediumsize enterprises, and adapting the educational structure of school graduates to market needs in a more consistent way. funds.

Table 4 EUROPE 2020 strategic objectives for the Slovak Republic and EU

\begin{tabular}{|l||c|c|c|}
\hline Criterion & Conditions in SR 2012 & SR Objective (2020) & EU Objective \\
\hline \hline Employment & $65.1 \%$ & $72 \%$ & $75 \%$ \\
\hline $\begin{array}{l}\text { Expenditure for science, research and } \\
\text { innovation as GDP\% }\end{array}$ & $0.63 \%$ & $1 \%$ & $3 \%$ \\
\hline Greenhouse gas emissions & & $-13 \%$ compared to 2005 & $-20 \%$ compared to 1990 \\
\hline Renewable energy in \% of total demand & $9.8 \%$ & $14 \%$ & $20 \%$ \\
\hline Energy Consumption & & $-20 \%$ compared to 2005 & $-20 \%$ compared to 2005 \\
\hline Early termination of education programs (max) & $5 \%$ & $6 \%$ & $10 \%$ \\
\hline $\begin{array}{l}\text { Share of young people (aged 30-34) on tertiary } \\
\text { education }\end{array}$ & $23 \%$ & $40 \%$ & $35 \%$ \\
\hline Share of population at risk of poverty & $20 \%$ & $\begin{array}{c}\text { to be reduced by } 170000 \\
\text { compared to } 2005\end{array}$ & $\begin{array}{c}\text { to be reduced by } 20 \text { million } \\
\text { compared to } 2005\end{array}$ \\
\hline
\end{tabular}

Source: EU Commission, 2012 


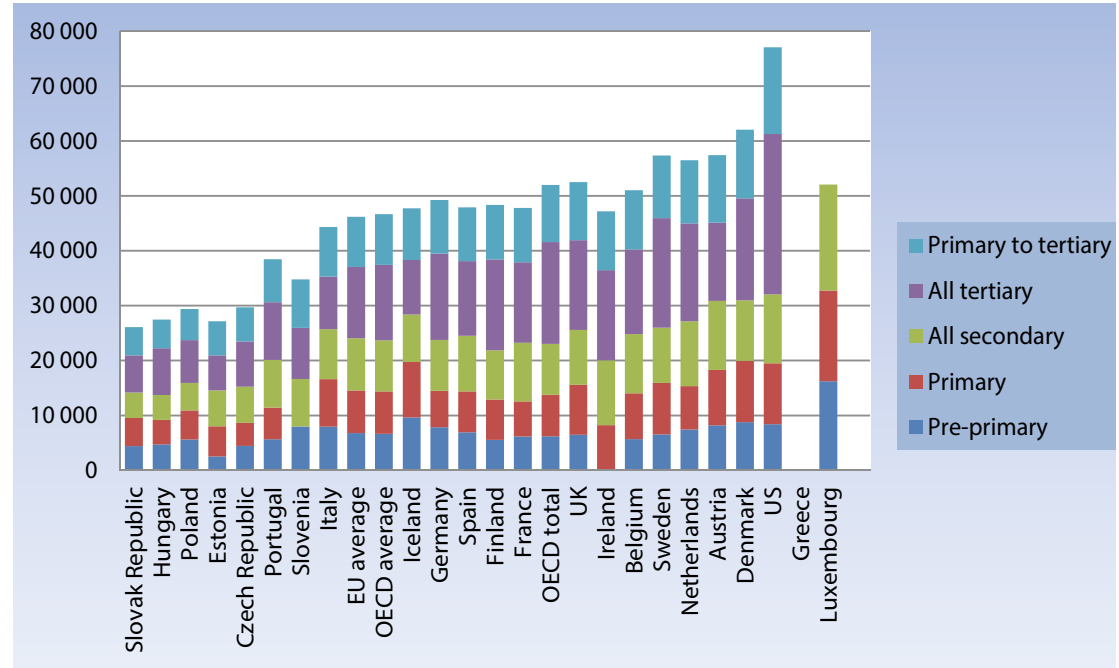

Figure 4 Annual expenditures per student USD PPS, 2009 Source: OECD, 2010, author

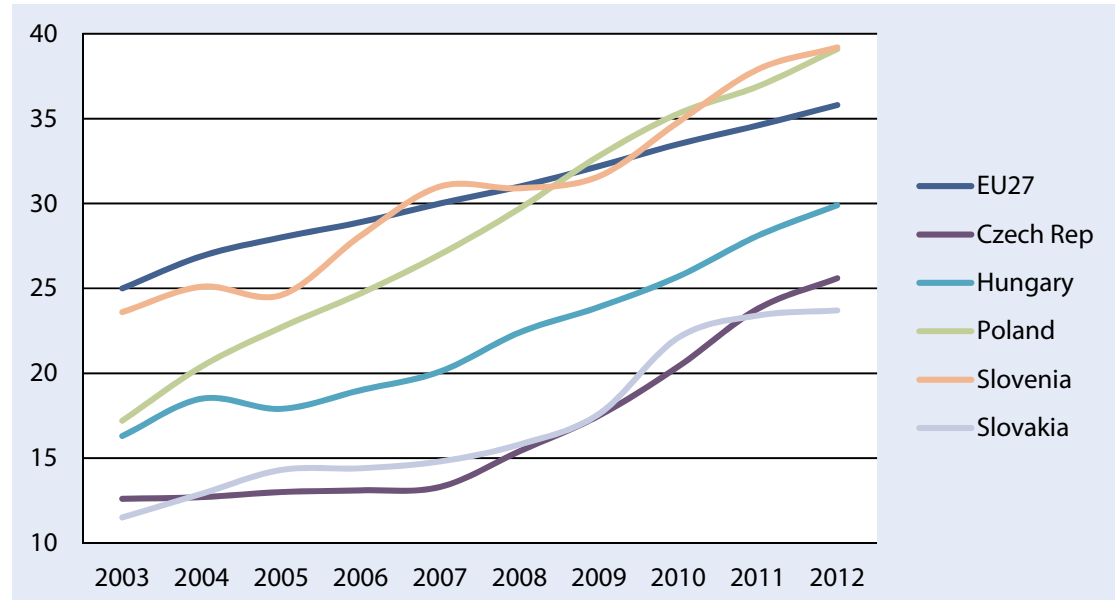

Figure 5 Dynamics in number of graduates in ISCED 5-6 in Visegrad countries. and EU27

Source: EU Commission, 2012, author

Most of the new Member States of the Union should invest much more in their education and science and research sectors. In case of Slovakia, the situation has been known for a long time. According to OECD statistics, Slovakia scores low in the assessment by the volume of resources allocated per student in the school system as indicated in Figure 4 below.

In connection with the recurring problems of the financial security of educational institutions, particularly those that are expected to provide direct innovation outputs, the reality of the envisaged increase in the numbers of graduates is questioned as assumed by the Europe 2020 strategy and presented in Figure 5 for the countries of the Visegrad Group. Without addressing the need for financial direct impact of such approach will be further expressed in a form of the econometric model linking all relevant data for exploring their impact (direct and indirect) on the innovation progress, economic growth and better functioning labour market.

Europe 2020 as a strategic document is worded clearly and in a binding way. It is expected that Member States will implement it in a consistent way, i.e. including its financial and material base as well. If there are no clearly defined and long respected commitments towards the research and development sector on the part of the state, even the best prepared document may become only another in the number of declaratively defined objectives In this case, however, even the solution of serious problems like unemployment and risk of poverty will surely become only an outstanding commitment.

\section{Conclusion}

The program document of the European Union EUROPE 2020 contains the important commitments and objectives which the EU intends to meet by 2020 in order to ensure its international competitiveness in the global economic space and reach the innovation activity of USA and Japan as its main partners. These goals were adopted under the general consensus of all Member States. It is expected, therefore, that their implementation will be consistent both in time and content.

As a particularly important task, which requires urgent solution, it is necessary to extend the space for higher employment of highly skilled labour in the EU and individual countries as stated in the development objectives for 2020. Main attention should be paid to economic sectors with the most significant impact on innovation processes in manufacturing. These are the sectors focusing on IT technologies. This orientation imposes new obligations on educational institutions of all levels, in order to ensure that the conditions are established for these development programs already at lower levels of education. 


\section{References}

STIGLITZ, J. - SEN, A. 2010. Report by the Commission on the Measurement of Economic and Social Progress. In: OECD, 2010 EUROPA. 2020. http://ec.europa.eu/europe2020/index_sk.htm, 2012

JOINT POLITICAL Declaration Relations between the European Community and its Member States and USA, http://trade. ec.europa.eu/doclib/docs/2006/september/tradoc_113465.pdf RESHAPING the EU-US Relations: http://www.notre-europe.eu/ media/Etude75-EU-US_Relations-en_01.pdf, 2012

EU-JAPAN Overall Relationship: http://eeas.europa.eu/japan/ relationship_en.htm, 2012

JOINT DECLARATION on Relations between the European Community and its Member States and Japan, http://eeas. europa.eu/japan/docs/joint_pol_decl_en.pdf, 2012

ZOPPE, A. et al. 2011. Social Cohesion and Demographic Development in a Sustainable Europe. Development in a Sustainable Europe : seminar December, Brussels, 2011

HEYES, J. 2013. Flexicurity in crisis: European labor market policies. In EJIR, vol. 19, 2013, no. 1.

PACI, P. - REVENGA, A. - RIJKERS, B. 2011. Coping with Crises: Policies to protect employment and earnings. In The World Bank Research Observer, vol. 27, 2011, no. 1.

SPERMAN, A. 2005. Fighting Long-Term Unemployment with Targeted Employment Subsidies. In Journal of Economics and Statistics, J-L University Giesen, 2005
UIPMŠ. Štatistická ročenka. 2012

ROTH, F. - THUM, A. E. 2010. The key role of education in the Europe 2020 Strategy. CEPS Working document 338, 2010

KATTEL, R. 2009. The rise and fall of the Baltic States, http:// www.halduskultuur.eu/2009/KattelBalticStates.pdf,2009

GOEDEME, T. 2013. The standard error of estimates based on EU-SILC. An exploration through the Europe 2020 poverty indicators, unpublished papers, http://works.bepress.com/tim goedeme/13/, 2013

NOLAN, B. - WHELAN, C. 2010. Using non-monetary deprivation indicators to analyze poverty and social exclusion: Lessons from Europe? In Journal of Policy Analysis, Wiley Online Library, 2010 MARLIER, E. - NATALI, D. 2010. EUROPE 2020. Towards a more social EU? In P.I.E. PETER LANG S.A., Brussels, 2010

FAGERBERG, J. et al. 2005. Innovation. Oxford University Press The Oxford Handbook, 2005

HOLLANDERS, H. 2008. Rethinking the European Innovation Scoreboard. Pro Inno Europe, 2008

\section{Contact address:}

Ing. Libor Kabát, Slovak University of Agriculture in Nitra, Slovak Republic, Tr. A. Hlinku 2, 94976 Nitra, e-mail: libor. kabat@gmail.com 